

RESEARCH ARTICLE

\title{
PARENTING PROGRAM EVALUATION (EVALUATION STUDY AT TAMAN PENGASUHAN MAKARA (TPAM) INDONESIA UNIVERSITY OF DEPOK).
}

\author{
Ririn Tjahyaningsih, Myrnawati Crie Handini and M. Syarief Sumantri. \\ Universitas Negeri Jakarta.
}

\section{Manuscript Info}

Manuscript History

Received: 01 March 2018

Final Accepted: 03 April 2018

Published: May 2018

Keywords:-

Evaluation, Parenting Program.

\section{Abstract}

The objective of the research was to evaluate the parenting program at Taman Pengasuhan Makara Indonesia University (TPAM UI) of Depok, observed from the components of context, input, process, product, and outcomes (CIPPO). This research type is Program Evaluation Research. Based on research finding, the researcher concluded that: 1) Context aspect, TPAM UI has had constitution in program realization, 2) Input aspect, TPAM UI in parenting program realization has had certain purpose conducted the program, presented the expert informant, appropriate facility, but has not specific institution curriculum yet in parenting program and lack of stakeholders' supports. 3) Process aspect, Socialization in preparation plan of parenting event realization was conducted through social media, but the institution did not coordinate with parents about perception equality of the event, the necessity of program for parents. In implementation of the program, it was applied the variety of programs based on the necessity and the parents were not involved in materials decision given, 4) Product aspect, parents' understanding about nutrition, health, nurturing, parenting, education, and protection in concluding has shown the good result or satisfied, 5) Outcomes aspect, habit transfer from parenting program children has developed well for 6 fields (nutrition, health, nurturing, parenting, education, and protection).

Copy Right, IJAR, 2018,. All rights reserved.

\section{Introduction:-}

The education congruence which held at the preschool institution (early school) and home is avowed by the experts of education as a determine factor of children education success comprehensively. That is why it is important for the institution which handles an early childhood to facilitate the implementation of institution program based on family (parenting) as a congruence and continuously efforts between education which is held in early childhood institution and homeschooling (Kementrian Pendidikan Nasional, 2012: 2). This program is specified to the parents, caretaker, and other family members who are involving in expansion process of children directly, so the parents have an appropriate understanding connected to nurturing and children's growths.

The Research and Policy Committee Economic Development claimed that education for children is very necessary for the nation future (Marisson 2008:20). The Barth Et Al (2008:15) research, found that parenting program which 
existed in deposit place will give a new knowledge to the parents how is the way to interfere earlier for the children with specific needs particularly.

Ralph Tyler defines program evaluation as a process to know has education purpose been realized, Cronbach and Stufflebeam state that program evaluation is an attaining in reserving information, and deliver it to policy maker (Arikunto 2009: 5).

Hoghughil (2004: 86) states that parenting includes the kinds of activity which proposes to make children able to grow optimally and survive. Parenting principle according to Hoghugil is not pressured to whom but to the activity development and children's education. Therefore, parenting is covering physical parenting, emotional parenting, and social parenting. Syamsudin (2012:19) expresses that PAUD program evaluation based on family (parenting program) is a process to grade or measure an achievement of PAUD implementation based on family which held in PAUD institution or other institution.

The one interesting executor of TPA in Depok city to which the research is Taman Pengasuhan Anak (TPA) Makara UI that is existed at faculty of Psychology of Indonesia University, Depok West Java province. This TPA is in under of the four faculties control such as: Psychology Faculty, Medical Faculty, Faculty of Dentistry, and Faculty of Health and Nutrition. Based on the early result of research found that TPA Makara UI had existed since 2008 years ago until the parenting research held but it is not composed or in its implementation was not scheduled systematically. Parenting program was still incidental or suddenness. This situation is contrast with the institution's potential. Start from this, the researcher would mind to evaluate parenting program that was conducted at TPA of Makara UI Depok.

\section{Research Method:-}

This research is an evaluation study that is conducted at Preschool Taman Pengasuhan Anak Makara (TPAM) Indonesia University which located in Depok, West Java Province. The focus of research is parenting program evaluation at Taman Pengasuhan Anak. The research used evaluation method with qualitative approach. By evaluation method, may this research can have the researcher could assess or recognize the rate achievement effect of advantage and disadvantage of parenting program eventually.

Evaluation method is used to know the quality of program that has conducted by measurement of how far the policy can be implemented; it is usually through comparing with the standard. The oftentimes model used in evaluation of education program outside school is CIPPO model. CIPPO is an abbreviation of Context, Input, Process, Output, and Outcome (Stufflebeam1984: 144). Nevertheless, the design of the research was adapted to evaluation model which had discussed such as Context, Input, Process, Product, and Outcomes (CIPPO). This model was arranged to complete the base construction of decision in system evaluation by analysis oriented to the systematic change.

This research design of evaluation study is being logical frame evaluation to collect data, interpreting, and conclusion or recommendation. It was constructed to show the general view to the process of evaluation through the first stage until last stage of research. Research design is shown in the figure bellow: 


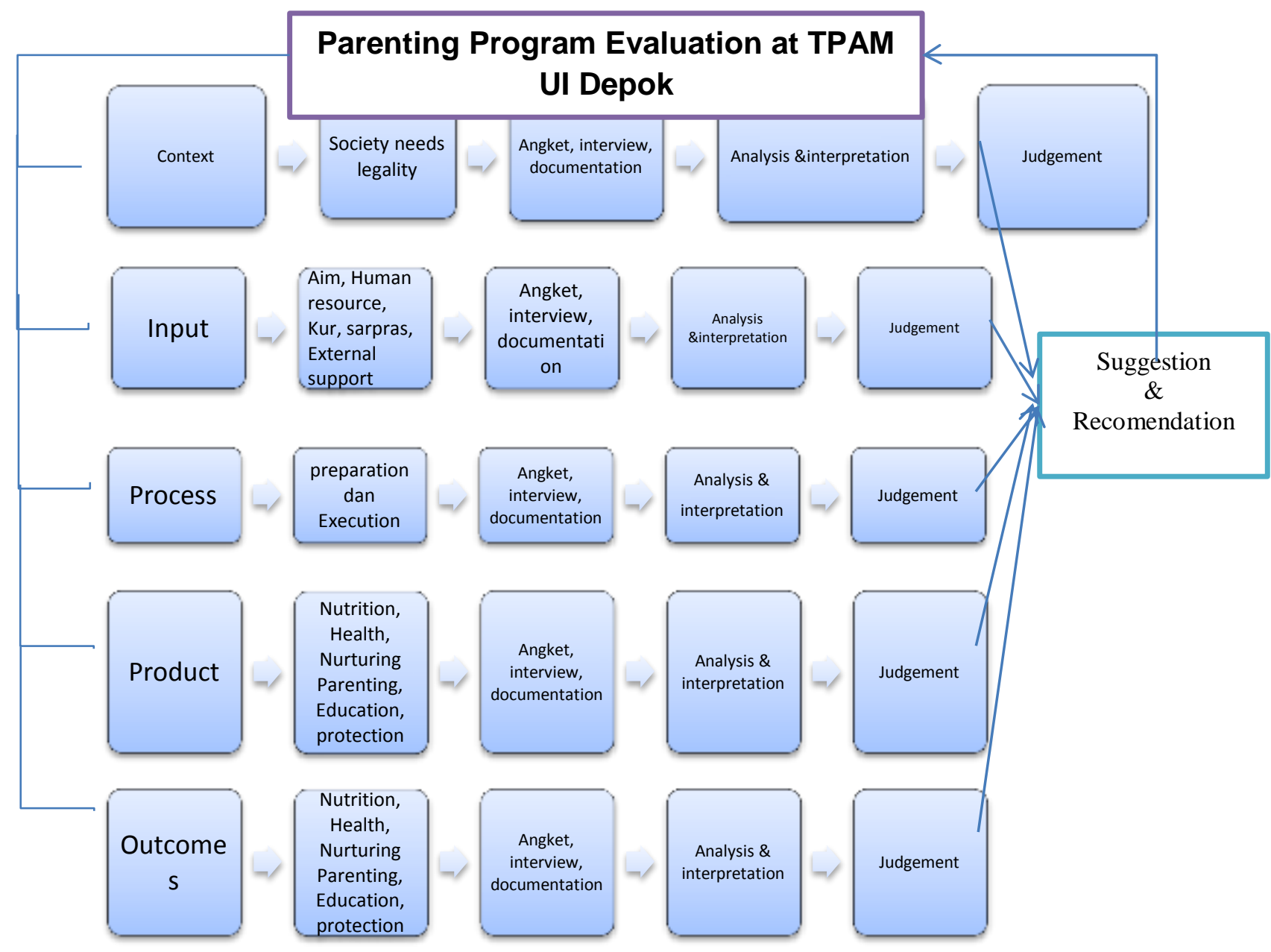

Figure 1;-Research Design

\section{Research Findings And Discussion:-}

Be based on Evaluation result, the effectiveness of parenting education implementation at Taman Pengembangan Anak Makara (TPAM) UI Depok city, could be evaluated by the aspects in CIPPO as follow:

\section{Component of Context:-}

In the context component of parenting program at Taman Pengembangan Anak Makara (TPAM) UI Depok city can be analyzed that the advantage and disadvantage with recommendation below:

\section{Advantages:-}

1. Taman Pengasuhan Makara UI was built by Psychology Faculty cooperated with 3 faculties, they are Medical Faculty, Faculty of Dentistry, and Faculty of Health and Nutrition Indonesia University, finally the controlling of children growths is been taken by the institution.

2. Taman Pengasuhan Makara UI has program implementation instruction that made by the four faculties until the technique journal of parenting program implementation is being a unit program development in TPAM UI.

\section{Disadvantages:-}

1. The operational license formal legality of TPAM UI construction has been occurred but it is in the extension license time and does not extend immediately.

2. TPAM UI is not joining PAUD miter organization in Depok, so they often could not have information about PAUD recently issue in Depok.

3. Bureaucracy at Indonesia University is very complicated; it is hard for them in making incidental policy. 
4. The administration system of college is not documented properly yet.

5. Attendance participation of parents is lowest at the parenting founding event which was held by Taman Pengasuhan Makara UI.

Recommendation:-

Study from the result analysis of advantage and weaknesses at context aspect in this research, this will be recommended to:

1. To extend the operational license of TPAM UI. Hopefully, there will be a coordination and observation of the PAUD event quality by Educational department as possible as technique instruction of TPA, Holistic Integrative PAUD and Technique Journal of parenting program which is being Family Educational Directory at Culture and Educational Ministry.

2. Committing the parenting guidance for the parents continuously (schedule) for instance once a month or two months which had delivered earlier (at parents beginning orientation of academic year) or adapting to its time and execution subject as parents' needs.

3. Documenting school administration into administrative file that arranged in order to support TPAM program comprehensively.

Component of Input:-

Component of input in parenting program at Taman Pengembangan Anak Makar (TPAM) UI Depok can be analyzed its advantage, disadvantages and recommendation as follow:

\section{Advantages:-}

1. Generally, the parents who entrusted their children to TPAM UI are educated people and they do easier to recognize parenting program that planned by TPAM UI institution.

2. TPA Makara UI has best facilities that used in parenting program.

3. Supporting from each faculty which backs up TPA Makara UI is significantly executing the parenting program like presented outside informant easily.

4. TPA Makara UI has a concept "school function is not changing parents' role at home". This makes parenting program can accept directly to neither parents nor alternated parents.

5. The recruitment of teachers and educational administrator are reformed selectively, thus the teacher has good qualification.

\section{Disadvantages:-}

1. TPA Makara UI does not have infinitive board of parenting program as school committee or POMG thus the activity disposes to hold aside by the institution.

2. TPA Makara UI has not technique journal of parenting program for specific board, thus the program realization is not becoming an attention yet.

\section{Recommendation:-}

1. Properly, it should involve parents in management of the program at TPA Makara UI.

2. It needs specific journal in the institution adapted to parents' necessity at the organization.

\section{Component of Process:-}

In the component of process at Taman Pengembangan Anak Makara (TPAM) UI Depok, can be defined the advantage and disadvantage of it follows with recommendation below:

\section{Advantages:-}

1. Children Learning Program has designed into the program which needs parents' interference.

2. Coordinator and co coordinator creativity in designing the program school of a year is also involving parents' role.

\section{Disadvantages:-}

1. TPA Makara UI has not parenting program committee.

2. Arrangement of parenting program schedule decided directly by the school (not including parents). 


\section{Recommendation:-}

1. It is better if the parenting program board consisted of parents.

2. Creating the special parenting program for parents continuously and trying to be consistent apply it.

\section{Component of Product:-}

In component of product of parenting program at Taman Pengembangan Anak Makara (TPAM) UI, Depok was analyzed about the advantage and disadvantages with recommendation as follows:

\section{Advantages:-}

1. The school has several parenting programs that most connected to nutrition matter, health, nurturing, education, parenting, and protection.

2. The students' parents are mostly the educated people thus relatively easy to understand the activity held.

\section{Disadvantages:-}

1. The school does not control the progress of parenting program which ever held.

2. Most of the parents are the part-time workers, so the communication is very limited.

\section{Recommendation:-}

This is necessary to record the evaluation of parenting program implementation through some Medias.

\section{Component of Outcomes:-}

This component was analyzed that there is a change in children personality. This is identified from repeating habits simply at the school, such as: children like vegetable weather did not like it before. They can choose the good and bad foods for themselves. The children should be independent at school either at home.

\section{Conclusion:-}

As the data analysis, the parenting program on parents education executed effectiveness at Taman Pengembangan Anak Makara (TPAM) UI, Depok can be concluded as follow:

\section{Context aspect:-}

The base formal implementation of parenting program at Taman Pengasuhan Anak Makara (TPAM) UI Depok has had constitution such as reference book of National Education Ministry Regulation No. 58 year 2009 about PAUD standardization became learning standard not only parenting program. Meanwhile, parenting program also be based on technique journal implementation of parenting, the journal was a standard that used by researcher as reference book of research in this evaluation.

\section{Input Aspect:-}

TPAM UI definitely has: a) the purpose of program realization such as socializes to the parents about learning formation which is held in TPAM UI also constructed the perception equality between school and parents in the institution. b) Human resource like presenting the informant which is originally from the four faculties (psychology, Nursery, Medical, and Dentistry) and guest informant from the parents who competed being a informant. c) Parenting program curriculum at TPAM UI is not prepared specifically, but spontaneously existed based on necessity. d) The support facility at TPAM UI such as variety media (LCD, picturing tape, etc) based on the needs in matters delivery. e) Parenting Program Realization Support from Educational Department is very low at TPA Makara UI Depok.

\section{Aspek Process:-}

Comprehensive parenting program service that was conducted TPA Makara UI Depok West Java includes: 1) Prepared planning of parenting program realization was done by socializing the program schedule to the parents through social media, but the institution did not execute coordination with parents about perception equality on the event, the importance of event for the parents. 2) Execution of parenting program was realized by several kinds of activity appropriated to the necessity in children development, however the parents are not comprised in subject allowing.

\section{Product aspect:-}

By parenting program at PAUD Makara UI includes the understanding of parents about a) Nutrition, b) Health, c) nurturing, d) parenting, e) education, and f) protection should be nodded that it is showing the satisfied result. 


\section{Outcomes aspect:-}

The changing of children's habit through parenting program had developed properly in six fields (nutrition, health, nurturing, parenting, education, and protection).

\section{Bibliography:-}

1. Arikunto Suharsimi dan Cepi Safrudin, Evaluasi Program Pendidikan: Pedoman Teoritis Praktis Bagi Mahasiswa dan Praktisi Pendidikan, Jakarta: Bumi Aksara, cet. 3, 2009.

2. Anon, Kementerian Pendidikan Nasional, Pedoman Penyelenggaraan Pendidikan Anak Usia Dini Berbasisi Keluarga, Jakarta: Direktorat Pembinaan Pendidikan Anak Usia Dini, NonFormal dan InFormal, 2012

3. Barth Richard P. et al, Parent-Training Programs in Child Welfare Services: Planning for a More EvidenceBased Approach to Serving Biological Parents, Research on Social Work Practice, DOI: 10.1177/1049731505276321, Research on Social Work Practice 2005; 15; 353, sage publications, 2008.

4. Marisson George S Early Childhood Education Today, Columbus: Merrill Publishing company, 2008

5. Hoghugi M, Long N, Editor. Handbook Of Parenting Theory And Research For Practice, London: Sage Publication, 2004

6. Syamsuddin,Erman Pedoman Penyelenggaraan Pendidikan Anak Usia Dini berbasis Keluarga, Jakarta : Direktorat Pembinaan Anak Usia Dini,2012

7. Stufflebeam Daniel. L dan Anthony. J.Shinkfield, Systematic Evaluation. Boston: Kluwer Nijhoff Publishing, 1984. 